\title{
Soil solution and plant nitrogen on irrigated rice under controlled release nitrogen fertilizers
}

\section{Thais Antolini Veçozzi ${ }^{* *}$ Rogério Oliveira de Sousa ${ }^{2}$ Walkyria Bueno Scivittaro ${ }^{3}$ Cristiano Weinert ${ }^{2}$ Victor Raul Cieza Tarrillo}

${ }^{1}$ Departamento de Solos, Universidade Federal de Pelotas (UFPel), 96010-900, Pelotas, RS, Brasil. E-mail: thais_antolini@hotmail.com. ${ }^{*}$ Corresponding author.

${ }^{2}$ Universidade Federal de Pelotas (UFPel), Pelotas, RS, Brasil.

${ }^{3}$ Embrapa Clima Temperado, Pelotas, RS, Brasil.

\begin{abstract}
A study was conducted to evaluate the solubilization and nitrogen (N) use efficiency (NUE) of controlled release nitrogen fertilizers in irrigated rice, compared to urea. It was developed under semi-controlled conditions, including five treatments: Control, Splitted Urea (pre-sowing and topdressing), Pre-sowing urea, and Polymer Coated Urea (PCU) with 60-day and 90-day release. PCUs did not maintain high $\mathrm{NH}_{4}^{+}$and $\mathrm{NO}_{3}^{-}$levels in solution over a longer period than urea. NUE of PCUs was similar to uncoated urea, not increasing nutrient release in irrigated rice field.
\end{abstract}

Key words: nitrogen fertilization, polymer coated urea, efficiency, flooded soil.

Nitrogênio na solução do solo e em plantas de arroz irrigado sob adubação com fertilizantes nitrogenados de liberação controlada

RESUMO: Realizou-se um trabalho para avaliar a solubilização e eficiência de uso de nitrogênio (N) de fertilizantes nitrogenados de liberação controlada em arroz irrigado, comparando-os à ureia. O experimento foi realizado sob condições semi-controladas, incluindo os tratamentos: Testemunha, Ureia aplicada de forma parcelada, Ureia aplicada em pré-semeadura e Ureia Recoberta por Polímeros (URP) com tempo de liberação de $N$ de 60 e 90 dias, aplicada em pré-semeadura. As URPs não mantiveram os teores de amônio e nitrato em solução por periodo superior ao da ureia. A eficiência de uso de $N$ das URPs avaliadas foi semelhante à da ureia não recoberta, não aumentando o tempo de liberação do nutriente em cultivo de arroz irrigado.

Palavras-chave: adubação nitrogenada, ureia recoberta por polímero, eficiência, solo inundado.

Nitrate $\left(\mathrm{NO}_{3}^{-}\right)$and ammonium $\left(\mathrm{NH}_{4}^{+}\right)$, mineral nitrogen forms uptaken by plant roots, are susceptible to soil losses in the processes of nitrification, denitrification, ammonia $\left(\mathrm{NH}_{3}\right)$ volatilization and $\mathrm{NO}_{3}$ leaching, under variable magnitudes as a function of environmental conditions, especially humidity, aeration and temperature (CAMERON et al., 2013). In soils cultivated with irrigated rice, $\mathrm{N}$ losses are associated, mainly, to the increase of its concentration in soil solution in response to nitrogen fertilizer application and to alternate wetting and drying soil conditions that lead to nitrification/denitrification processes (PONNAMPERUMA, 1972).

The application of nitrogen fertilizers aims to increase the $\mathrm{N}$ mineral soil amount that, in general, does not supply the crop demands.
However, the efficiency of conventional $\mathrm{N}$ sources for irrigated rice rarely exceeds $50 \%$ due to losses. The most practical management measure adopted to minimize $\mathrm{N}$ soil losses is the adjustment of fertilizer application to the crop needs. For irrigated rice, the $\mathrm{N}$ management measures recommended includes the partitioning of doses in such a way that the nutrient will be available to the plants in the higher demand periods, i.e., at both the beginning of tillering and reproductive phase (SOSBAI, 2014).

The technology of increased efficiency fertilizers, such as those with controlled and slow release, stabilized with enzymatic inhibitors provides a potential alternative to reduce $\mathrm{N}$ losses and to improve $\mathrm{N}$ use efficiency and, consequently, crop yields. The controlled release fertilizers (CRF) 
are conventional fertilizers coated with material having low solubility in water, slowly releasing this nutrient to the soil (LINQUIST et al., 2013; CAMERON et al., 2013).

The performance of CRF in flooded soils is still barely known, especially under irrigated rice conditions in Rio Grande do Sul State, Brazil, requiring better understanding in order to verify the economical and environmental viability of adopting this technology. Therefore, the present study had the objective of evaluating the solubilization and the $\mathrm{N}$ use efficiency of CRF for the irrigated rice crop, when compared to urea.

The experiment was performed in greenhouse, at the Universidade Federal de Pelotas (UFPel), Capão do Leão-RS. The treatments were: 1. Control - without N; 2. Urea split in presowing $\left(10 \mathrm{~kg} \mathrm{~N} \mathrm{ha}^{-1}\right)$ and topdress, at 12 days after emergence (DAE), four leaf stage - V4 $\left(55 \mathrm{~kg} \mathrm{~N} \mathrm{ha}^{-1}\right)$ and at 34 DAE, eight leaf stage - V8 $\left(55 \mathrm{~kg} \mathrm{~N} \mathrm{ha}^{-1}\right)$; 3. Urea at pre-sowing incorporated into soil; 4 . PCU 60 - polymer coated urea $(39.6 \% \mathrm{~N}, \mathrm{CRF}$ presenting $30 \%$ and $100 \% \mathrm{~N}$ with release at 15 and 60 days after application, respectively) at pre-sowing, incorporated into soil; 5. PCU 90 - polymer coated urea $(39.4 \% \mathrm{~N}$, CRF presenting $20 \%, 80 \%$ and $100 \% \mathrm{~N}$ with release at 15,60 and 90 days after application, respectively) at pre-sowing, incorporated into soil. The recommended $\mathrm{N}$ dose was $120 \mathrm{~kg} \mathrm{ha}^{-1}$, established as a function of soil chemical analyses results for predicted high fertilizer response (SOSBAI, 2014).

Treatments were disposed in random block design with four replications. The experimental units consisted of $8 \mathrm{dm}^{3}$ pots, containing $7.2 \mathrm{~kg}$ of soil originating from a superficial layer sample $(0-20 \mathrm{~cm})$ of a Albaqualf previously sieved in $10 \mathrm{~mm}$ mesh. Results from the soil chemical analyses were the following: clay $=24.7 \% ; \mathrm{pH}_{\text {water }}(1: 1)=5.1 ; \mathrm{P}=5.4 \mathrm{mg} \mathrm{dm}^{-3} ; \mathrm{K}$ $=32.3 \mathrm{mg} \mathrm{dm}^{-3}$; O.M. $=0.9 \% ; \mathrm{Ca}=2.0 \mathrm{cmol}_{\mathrm{c}} \mathrm{dm}^{-3}$; $\mathrm{Mg}=1.1 \mathrm{cmol}_{\mathrm{c}} \mathrm{dm}^{-3} ; \mathrm{Al}=0.6 \mathrm{cmol}_{\mathrm{c}} \mathrm{dm}^{-3} ; \mathrm{CEC}_{\text {effective }}$ $=3.9 \mathrm{cmol}_{\mathrm{c}} \mathrm{dm}^{-3} ; \mathrm{CEC}_{\mathrm{pH} 7}=7.5 \mathrm{cmol}_{\mathrm{c}} \mathrm{dm}^{-3}$ and base saturation $=45 \%$ (TEDESCO et al., 1995).

At pre-sowing, the $\mathrm{N}$ sources were applied at $5 \mathrm{~cm}$ depth, at amounts corresponding to the calculated doses for each treatment. The soil received, also, phosphate (triple superphosphate $100 \mathrm{~kg} \mathrm{ha}^{-1} \mathrm{P}_{2} \mathrm{O}_{5}$ ) and potassium (potassium chloride - $120 \mathrm{~kg} \mathrm{ha}^{-1} \mathrm{~K}_{2} \mathrm{O}$ ) sources. These fertilizers were uniformly mixed to the soil of each pot. Soil solution extractors were installed at 5 and $10 \mathrm{~cm}$ depth during pot filling, according to Sousa et al. (2002). Four rice plants of cv. Puitá Inta CL were cultivated per pot. Rice irrigation by flooding started 13 DAE.
Soil solution sampling was performed at 2 , $9,15,23,30,37$ and 44 days after soil flooding. The $\mathrm{pH}$ and redox potential values (Eh) of the collected soil solution at $10 \mathrm{~cm}$ were determined by combined specific electrodes, according to Sousa et al. (2002). Also, $30 \mathrm{~mL}$ of soil solution were collected at 5 and $10 \mathrm{~cm}$ depths for determining ammonium $\left(\mathrm{NH}_{4}^{+}\right)$and nitrate $\left(\mathrm{NO}_{3}^{-}\right)$concentrations by steam destillation, with the help of a Kjeldahl distiller (TEDESCO et al., 1995). At 57 DAE, plants were harvested and shoot dry matter (SDM) and $\mathrm{N}$ content were determined. From this data, the $\mathrm{N}$ accumulated in the rice plants was calculated. The nitrogen use efficiency (NUE) was obtained by the difference between $\mathrm{N}$ accumulated in treatments and the control, divided by the used $\mathrm{N}$ dose.

Results obtained for $\mathrm{NH}_{4}^{+}$and $\mathrm{NO}_{3}^{-}$ concentrations in the soil solution and the evaluated plant parameters were subjected to analysis of variance and, when significant, the treatment means were compared by Tukey test $(\mathrm{P}<0.05)$, using the software Assistat ${ }^{\circledR}$.

The soil solution $\mathrm{pH}$ and Eh values during the evaluation period presented a typical behavior of flooded soils, i.e., reflected the usual variations for these electrochemical parameters observed for irrigated rice fields (Figures $1 \mathrm{~A}$ and $1 \mathrm{~B}$ ). At the initial flooding period, the Eh values were higher than $400 \mathrm{mV}$ and $\mathrm{pH}$ values lower than 5.0, still characteristic of an oxidated environment. As the time of flooding increased, Eh decreased and $\mathrm{pH}$ increased, stabilizing around $200 \mathrm{mV}$ and 6.2, respectively, which are characteristic of a reduced environment (PONNAMPERUMA, 1972).

Independent from treatment, $\mathrm{NH}_{4}^{+}$ concentration in the soil solution was higher at two days of soil flooding. At $5 \mathrm{~cm}$ depth, treatments with full $\mathrm{N}$ dose at pre-sowing showed higher $\mathrm{NH}_{4}^{+}$concentrations. One week later, the PCUs provided higher $\mathrm{NH}_{4}^{+}$concentrations (Figure 1C). At this moment, pre-sowing urea provided higher concentrations of $\mathrm{NH}_{4}^{+}$at $10 \mathrm{~cm}$ (Figure 1D). From the $15^{\text {th }}$ day of flooding, $\mathrm{NH}_{4}^{+}$concentrations in the solution were close to null for the treatments with $\mathrm{N}$ application, being equivalent to the control. There was not an increase in $\mathrm{NH}_{4}^{+}$concentration after the second cover application for the split urea treatment, probably because of high demand by the plants during this period.

The highest $\mathrm{NO}_{3}^{-}$concentrations in the soil solution were observed for the sampling performed two days after flooding. At $5 \mathrm{~cm}$ depth, the magnitude and variation in $\mathrm{NO}_{3}^{-}$concentrations was similar 


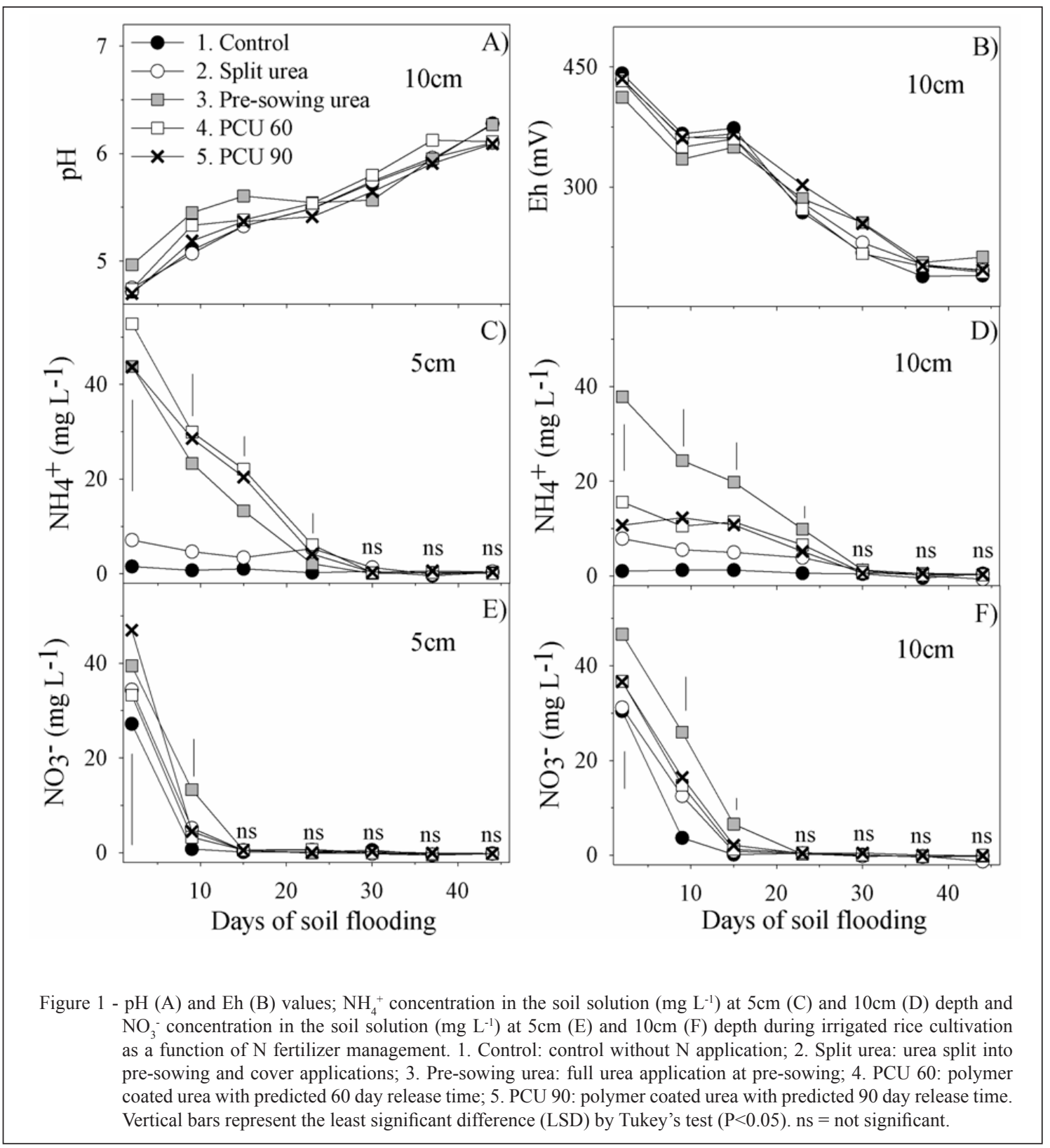

between treatments, with exception of urea applied at pre-sowing, which presented higher concentration than the remaining treatments $\left(13 \mathrm{mg} \mathrm{L}^{-1}\right)$ at the ninth day after flooding (Figure 1E). This treatment, as well as the other treatments receiving full $\mathrm{N}$ at pre-sowing, provided higher $\mathrm{NO}_{3}^{-}$concentrations in solution at $10 \mathrm{~cm}$ depth (Figure $1 \mathrm{~F}$ ). At both depths, $\mathrm{NO}_{3}^{-}$ concentrations reached values close to zero at the $23^{\text {rd }}$ day after flooding (Figures $1 \mathrm{E}$ and $1 \mathrm{~F}$ ). Decrease in $\mathrm{NO}_{3}{ }^{-}$values is faster than those of $\mathrm{NH}_{4}^{+}$as a function of nitrate reduction by flooding and consequent depletion of $\mathrm{O}_{2}$ in the soil (PONNAMPERUMA, 1972). Mineral $N$ concentration in the solution decreased with soil flooding, due to plant uptake and system losses, particularly in the nitrification/ denitrification processes (CAMERON et al., 2013).

The CRFs did not maintain $\mathrm{NO}_{3}^{-}$and $\mathrm{NH}_{4}^{+}$concentration values in the soil solution that were higher than urea for longer times. Therefore, these sources did not comply with their specifications regarding the $\mathrm{N}$ release period in soil flooded for rice cultivation. Similar results 
were obtained by JI et al. (2007) also working with irrigated rice. These authors reported that total $\mathrm{N}$ and $\mathrm{NH}_{4}^{+}$concentrations in soils fertilized with CRF were higher than those receiving urea only at the first 15 days after application. Conversely, RANSOM (2014) reported that some controlled release sources make $\mathrm{N}$ available at faster rates than predicted, an effect that seems associated with variations in daily temperatures.

Treatments with $\mathrm{N}$ application did not differ regarding to $\mathrm{N}$ content in the rice shoots and, except for the splitted urea application, they were similar to the control without $\mathrm{N}$ (Table 1). This result indicated that the irrigated rice management recommendations for south Brazil, where soluble $\mathrm{N}$ sources should be partitioned to reach the stages of higher demand by the plants, optimizes the use of this nutrient by the crop (SOSBAI, 2014). Regarding the variables dry matter, $\mathrm{N}$ accumulated in shoots and NUE by rice, higher values were detected for the treatments with $\mathrm{N}$ application, only when compared to the control, displaying non-significant differences between the various $\mathrm{N}$ sources. (Table 1). This indicated that native $\mathrm{N}$ was not enough to meet the crop demands.

The initial $\mathrm{N}$ demand for rice plants is relatively low due to the short plant stature. From the beginning of tillering on (between 20-30 DAE), this demand is increased, with little variations between cultivars (SOSBAI, 2014). In the present study, the maximum concentrations of $\mathrm{N}$ mineral forms in the soil solution occurred earlier than the high demanding plant stage, indicating a possible nutrient limitation during the highest crop demand period.
Results obtained agree with reports regarding $\mathrm{N}$ management for irrigated rice, where benefits from replacing soluble $\mathrm{N}$ sources by $\mathrm{CRF}$ were not seen (SLATON et al., 2009; MIAO et al., 2016). Unfavorable results regarding the use of covered sources can be explained by the reduction of its efficiency by soil flooding in the cultivation of irrigated rice. In this environment, fertilizer recover is subjected to a higher water dilatation and penetration, speeding the nutrient release rate.

There are studies, however, in which the use of controlled release fertilizers is very advantageous to the crop. In this sense, YANG et al. (2013) reported that a reduced $\left(125 \mathrm{~kg} \mathrm{ha}^{-1}\right)$ and full (187.50kg N ha-1) dose of CRF, when compared to the full urea dose, lead to grain yield and NUE increases. Recently, TAO et al. (2014) reported an increase in grain yield and NUE by irrigated rice, when using CRF compared to urea and urea treated with nitrification inhibitor. Such reports indicate that some increased efficiency sources can be beneficial to the rice crop. However, in order for them to be economically viable it is necessary that the increase in efficiency result in yield gains that compensate the investment on a higher cost product, therefore enabling the replacement of conventional sources.

The polymer coated ureas (PCUs) made the $\mathrm{N}$ more readily available than predicted in the cultivation of irrigated rice, not maintaining high $\mathrm{N}$ mineral contents in the solution for longer time than urea. The NUE of PCUs was similar to the plain urea, not resulting in a longer time for nutrient release to the rice crop.

Table 1 - N content, dry matter production (DM), shoot accumulated $\mathrm{N}(\mathrm{AN})$ and nitrogen use efficiency (NUE) as a function of nitrogen fertilizer management.

\begin{tabular}{lcccc}
\hline Treatments & N content & DM & AN & NUE \\
\hline- & $\mathrm{g} \mathrm{kg}^{-1}$ & $\mathrm{~g}$ & $\mathrm{mg} / \mathrm{pot}$ & \\
1. Control & $13.3 \mathrm{~b}$ & $3.6 \mathrm{~b}$ & $48.0 \mathrm{~b}$ & \\
2. Split urea & $20.7 \mathrm{a}$ & $12.7 \mathrm{a}$ & $262.0 \mathrm{a}$ & $50.9 \mathrm{a}$ \\
3. Pre-sowing urea & $18.5 \mathrm{ab}$ & $12.9 \mathrm{a}$ & $238.8 \mathrm{a}$ & $45.4 \mathrm{a}$ \\
4. PCU 60 & $17.1 \mathrm{ab}$ & $12.2 \mathrm{a}$ & $208.7 \mathrm{a}$ & $38.2 \mathrm{a}$ \\
5. PCU 90 & $18.2 \mathrm{ab}$ & $11.6 \mathrm{a}$ & $211.2 \mathrm{a}$ & $38.8 \mathrm{a}$ \\
CV $(\%)$ & 18.43 & 7.79 & 12.93 & 13.58 \\
\hline
\end{tabular}

1.Control: control without $\mathrm{N}$ application; 2. Split urea: urea split into pre-sowing and cover applications; 3. Pre-sowing urea: full urea application at pre-sowing; 4. PCU 60: polymer covered urea with predicted 60 day release time; 5. PCU 90: polymer coated urea with predicted 90 day release time.

Means followed by the same letter, in columns, do not differ by the Tukey test $(\mathrm{P}<0.05)$. 


\section{ACKNOWLEDGMENTS}

To Universidade Federal de Pelotas (UFPel) and Embrapa Clima Temperado, for financial support, to Fundação de Amparo a Pesquisa do Estado do Rio Grande do Sul (FAPERGS) and Coordenação de Aperfeiçoamento de Pessoal de Nível Superior (CAPES), for providing fellowships to the first author and to Conselho Nacional de Desenvolvimento Científico e Tecnológico (CNPq) for providing a PQ fellowship to the second author.

\section{REFERENCES}

CAMERON, K.C. et al. Nitrogen losses from the soil/plant system: a review. Annals of Applied Biology, v.162, p.145-173, 2013. Available from: <http://onlinelibrary.wiley.com/doi/10.1111/aab.12014/abstract>. Accessed: Oct. 25, 2016. doi: 10.1111/aab.12014.

JI, X. et al. Study of dynamics of floodwater nitrogen and regulation of its runoff loss in paddy field-based two-cropping rice with urea and controlled release nitrogen fertilizer application. Agricultural Science in China, v.6, n.2, p.189-199, 2007. Available from: <http://www.sciencedirect.com/science/article/ pii/S1671292707600340>. Accessed: June 06, 2016. doi: 10.1016/ S1671-2927(07)60034-0.

LINQUIST, B.A. et al. Enhanced efficiency nitrogen fertilizers for rice systems: Meta-analysis of yield and nitrogen uptake. Field Crops Research, v.154, p.246-254, 2013. Available from: <http:// www.sciencedirect.com/science/article/pii/S0378429013002943>. Accessed: June 06, 2014. doi: 10.1016/j.fcr.2013.08.014.

MIAO, X. et al. Yield and nitrogen uptake of bowl-seedling machinetransplanted rice with slow-release nitrogen fertilizer. Soil Fertility and Crop Nutrient, v.108, n.1, p.313-320, 2016. Available from: $<$ https://dl.sciencesocieties.org/publications/aj/articles/108/1/313>. Accessed: Feb. 30, 2016. doi: 10.2134/agronj2015.0101.

PONNAMPERUMA, F.N. The chemistry of submerged soils. Advances in Agronomy, v.24,p.29-96, 1972. Available from: $<$ http://
www.sciencedirect.com/science/article/pii/S0065211308606331>. Accessed: Nov. 20, 2014. doi: 10.1016/S0065-2113(08)60633-1.

RANSOM, C.J. Nitrogen use efficiency of polymer-coated urea. 2014. 103f. Dissertação (Mestrado em Ciências) - Programa de PósGraduação em Plantas e Vida Selvagem, Brigham Young University. Available from: $<$ http://scholarsarchive.byu.edu/cgi/viewcontent. cgi? article $=4984 \&$ context $=$ etd $>$. Accessed: Oct. 08, 2014

SLATON, N.A. et al. Rice response to urea and two polymercoated urea fertilizers. B.R. Wells Rice Research Studies, v.581, p.211:219, 2009. Available from: <http://arkansasagnews.uark. edu/581-28.pdf $>$. Accessed: Mar. 19, 2014.

SOCIEDADE SUL-BRASILEIRA DE ARROZ IRRIGADO SOSBAI. Arroz irrigado: recomendações técnicas da pesquisa para o Sul do Brasil. Porto Alegre: SOSBAI, 2014 189p.

SOUSA, R.O. et al. Composição da solução de um solo alagado conforme a profundidade e o tempo de alagamento, utilizando novo método de coleta. Revista Brasileira de Ciência do Solo, v.26, p.343-348, 2002. Available from: <http:/www.scielo.br/ pdf/rbcs/v26n2/07.pdf>. Accessed: Mar. 12, 2014. doi: 10.1590/ S0100-06832002000200007.

TAO, Y. et al. Potential to improve $\mathrm{N}$ uptake and grain yield in water saving ground cover rice production system. Field Crops Research, v.168, p.101-108, 2014. Available from: $<$ http://www. sciencedirect.com/science/article/pii/S0378429014002500>. Accessed: May 21, 2017. doi: 10.1016/j.fcr.2014.08.014.

TEDESCO, M.J. et al. Análises de solo, plantas e outros materiais. Porto Alegre: Universidade Federal do Rio Grande do Sul, 1995. (Boletim técnico, 5). 2v.

YANG, Y. Controlled-release urea for rice production and its environmental implications. Journal of Plant Nutrition, v.36, n.5, 2013. Available from: <http://www.tandfonline.com/doi/abs/ 10.1080/01904167.2012.756892>. Accessed: Apr. 30, 2015. doi: $10.1080 / 01904167.2012 .756892$. 